\title{
An Overview about the Brazilian Photovoltaic Market Development
}

\author{
Larissa Ananda Hansen, Diorge Alex Báo Zambra \\ Departamento Interdisciplinar, Universidade Federal do Rio Grande do Sul, Tramandaí, Brazil \\ Email: larissa.hansen@ufrgs.br, diorge.zambra@ufrgs.br
}

How to cite this paper: Hansen, L.A. and Zambra, D.A.B. (2020) An Overview about the Brazilian Photovoltaic Market Development. Journal of Power and Energy Engineering, 8, 73-84.

https://doi.org/10.4236/jpee.2020.88006

Received: July 23, 2020

Accepted: August 22, 2020

Published: August 25, 2020

Copyright $\odot 2020$ by author(s) and Scientific Research Publishing Inc. This work is licensed under the Creative Commons Attribution International License (CC BY 4.0).

http://creativecommons.org/licenses/by/4.0/

\begin{abstract}
There are five main institutions that develop research and provide data regarding photovoltaic energy generation in Brazil, they are: Brazilian Electricity Regulatory Agency (ANEEL); Energy Research Office (EPE); International Renewable Energy Agency (IRENA); Institute for the Development of Alternative Energies in Latin America (IDEAL); and Greener (a research and consultancy company specialized in the photovoltaic solar energy sector). The reports provided by these institutions present a large volume of data and information, this factor makes hard task of understanding the Brazilian photovoltaic market. Therefore, this paper purposes to present an overview about the development of photovoltaic generation in Brazil, through of an unpublished compilation and analysis of the data provided by the institutions previously cited. For this, initially the factors that contributed to the implementation and expansion of this sector are presented. Following, it is presented the main resolutions for the implementation of distributed generation, as well as organizations responsible for the standardization, operation, testing and expected requirements for connection of renewable sources in the electrical system. Quantitative data about energy installed, number of installations approvals, distribution of installations by sector of society, number homologations by power range and cost distribution for the implementation of these systems are provided. Finally, the incentive policies, credit lines and future perspectives for the development of the photovoltaic sector in Brazil are presented.
\end{abstract}

\section{Keywords}

Photovoltaic Systems, Solar Power Generation, Solar Energy, Standardization, Governmental Factors

\section{Introduction}

Population growth and economic development have led to a significant increase 
in demand for electricity in recent decades [1]. Due to the territorial extension of Brazil and the predominance of hydroelectric generation, it is necessary to use long transmission lines to conduct electricity from the power plants to the major consuming centers, causing considerable technical energy losses [2]. The installation of distributed generation systems would help to reduce these losses, helping to alleviate the demand for electricity from the electricity grid, as well as reducing investments in capacity increase of substations and transmission lines [3] [4].

The Brazilian energy matrix is mainly composed of renewable sources of energy. Hydroelectric power plants account for $66.6 \%$ of the energy produced, however, they are strongly dependent on rainfall and in times of drought their generation capacity is reduced [5] [6]. The potential of hydraulic generation is much higher if compared to that of a photovoltaic power plant. However, it requires high initial investment and its construction extends for about several years, while a photovoltaic power plant is implemented in a short time, usually less than one year [5] [6].

Energy from the sun is the most abundant natural resource on Earth [7]. However, photovoltaic solar energy has the lowest installed capacity among the renewable energy sources present in the Brazilian energy matrix [7]. Among the factors that contribute to the expansion of photovoltaic generation, it can be highlight the geographical location of Brazil, which has much of its territory between the Tropics of Cancer and Capricorn, a region that provides high rates of incidence of solar radiation, including during the winter [8]. Another factor, it is the absence of pollutant emissions during the operation of photovoltaic systems. The environmental impacts of this type of energy are mainly related to the manufacture of photovoltaic modules and their discard. These impacts compared to emissions from thermal power plants are considered insignificant [6].

The costs of photovoltaic systems have dropped more than 100 times since 1950 , value higher than the cost reduction of any other technology in this period [9]. Over a long period, photovoltaic modules represented the largest share of the total costs of photovoltaic systems [10]. However, the production cost of this component has decreased significantly in the last years, so that the share of modules in the total cost of photovoltaic systems is currently below 50\% [6]. Reductions in the cost of photovoltaic modules are linked to improvements in production processes and efficiency gains associated with the adoption of news techniques to design photovoltaic cells. The investment costs of photovoltaic systems vary widely and depend on many factors, such as: location, configuration, type, and size of the system [6]. The lifetime of photovoltaic modules is usually 25 years, and manufacturers that meet international quality standards guarantee $80 \%$ of the nominal power of the module at the end of this period [11]. In contrast, inverters usually have warranties of 5 to 10 years, and the service life may extend slightly over this period [12].

The described scenario shows the main factors for the adoption of photovoltaic power generation in Brazil. This form of generation began to be adopted in 
2012, mainly by residential consumers after the creation of legislation that regulates microgeneration and the compensation of energy injected into the grid. Several institutions, of public and private nature, develop research, issue reports, and maintain a database regarding the generation of energy from different sources. The main institutions that make these activities are: Brazilian Electricity Regulatory Agency (ANEEL); Energy Research Office (EPE); International Renewable Energy Agency (IRENA); Institute for the Development of Alternative Energies in Latin America (IDEAL); and Greener (a research and consultancy company specialized in the photovoltaic solar energy sector). The information provided by these institutions is quite complete; however, they are often not properly presented, in addition to mixing information from different sources and locations in the world, factors that hinder the perception of the development of a source in a specific location. Although they bring data from the past, present and future projections, they hardly address the legislation and policies that contributed to the expansion of the sector and that may impact on future development. To fill this gap, this paper purposes aims to present an unprecedented overview of the photovoltaic generation market in Brazil, presenting legislation, quantitative data, factors that have promoted adhesion and projections for photovoltaic generation in Brazil.

Following, Section 2 presents the Brazilian legislation on distributed generation. In Section 3 an overview of the Brazilian photovoltaic generation will be presented. In Section 4, the incentive policies for photovoltaic power generation will be presented. Section 5 presents the credit lines available for the implementation of photovoltaic systems. Section 6 presents the prospects for photovoltaic generation. Finally, Section 7 will present the final considerations of the paper.

\section{Legislation}

Distributed Generation has two classifications: 1) microgeneration with installed power lower than or equal to $75 \mathrm{~kW}$; 2) Mini-generation with installed power higher than $75 \mathrm{~kW}$ and lower than or equal to $3 \mathrm{MW}$ for hydric sources, or 5 MW for other energy sources [13]. The laws that regulate distributed micro and mini generation, promulgated by ANEEL (Brazilian Electricity Regulatory Agency), are Normative Resolution No. 482/2012 [14], Normative Resolution No. 517/2012 [15] and Normative Resolution No. 687/2015 [16].

There are three regulatory bodies governing the distributed generation in Brazil: 1) ANEEL ensures the development of the electricity market and maintains the balance among its agents; 2) ONS (National Electric System Operator) coordinates the control of the operation of the electricity generation and transmission facilities of the SIN (National Interconnected System), under ANEEL's supervision and regulation; 3) CCEE (Chamber of Commercialization of Electric Energy) enables the trading of electric energy in the Brazilian energy market [17].

ANEEL defined the Distributed Generation in Brazil as power generating plants, with installations connected directly to the SIN or through costumer in- 
stallations regulated by the ONS [18]. The energy compensation system, also known as net metering, is the procedure adopted by Brazil, in which the energy generated by the costumer is used to discount of the unity electricity consumption [19].

Normative Resolution 482/2012 establishes standard, responsibilities, general conditions, and constructive characteristics of the generator connection system to the concessionaire's distribution grid. As well as standardizing the constructive characteristics of the connection point of the costumer unit, protection system, and the photovoltaic inverter [19]. Normative Resolution No. 517/2012 sets the rules for injecting surplus energy back into the grid in exchange for credits.

Regarding the specifications related to certification and standardization, it stands out INMETRO (National Institute of Metrology, Quality and Technology) and ABNT (Brazilian Association of Technical Standards). In 2011 January, INMETRO published Ordinance 004, which deals with the "Conformity Assessment Requirements for Photovoltaic Systems and Equipment" [20]. Later, in 2012, it was established that all photovoltaic systems can only be marketed if they meet the requirements presented in the 2011 publication.

ABNT already has the following rules regarding the photovoltaic system: 1) ABNT NBR IEC 62116: 2012-Anti-islanding test procedure for photovoltaic inverters connected to the grid; 2) ABNT NBR 16149: 2013-Photovoltaic (PV) systems-Characteristics of the interface of connection to the distribution grid; 3) ABNT NBR 16150: 2013-Photovoltaic (PV) systems-Characteristics of the connection interface to the distribution grid-Conformity test procedure; 4) ABNT NBR 16274: 2014-Grid connected photovoltaic systems-Minimum requirements for documentation, commissioning testing, inspection and performance evaluation.

\section{Brazilian Photovoltaic Generation Overview}

The adequacy of the legislation regarding the distributed generation of electricity was important for the development of this sector, which since 2015 has shown significant growth in the number of installations directly connected to the distribution grid. Among all the sources of distributed generation in the country, it stands out photovoltaic solar, with $63.5 \%$ [21] of the total installed capacity. Figure 1 shows the four main sources of distributed generation and the exponential growth in the photovoltaic sector, which increased over $4000 \%$ in 4 years.

Until 2018 the installed capacity of photovoltaic systems was approximately $2360 \mathrm{MW}$ [21], with $562 \mathrm{MW}$ of distributed generation and $1798 \mathrm{MW}$ of Public Service Centers (SP) and Self-Producers (APE), as shown in Figure 2. The installed capacity in photovoltaic generation in Brazil still has an exceptionally low value compared to its energy potential. This is evident when comparing the potential of Brazilian photovoltaic generation with other countries, such as Germany, which has a territorial extension of the size of the state of Mato Grosso do Sul and has an installed capacity of 45,932 MW [22]. 


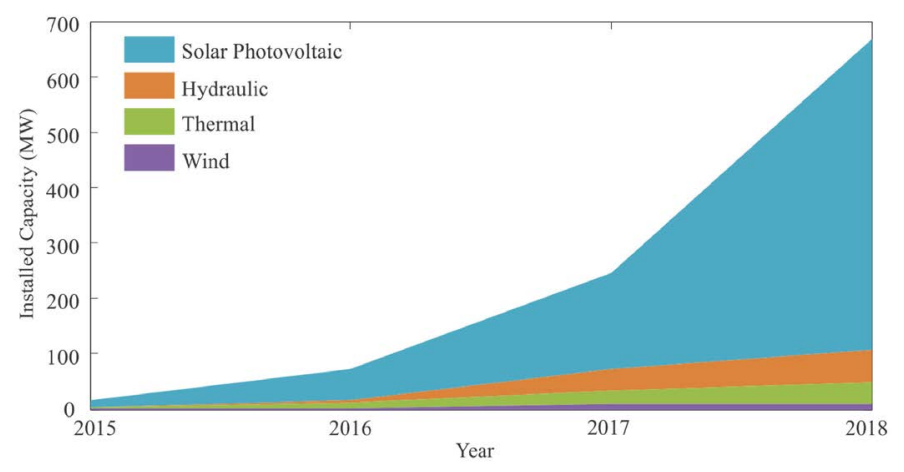

Figure 1. Distributed generation installed capacity in Brazil [21].

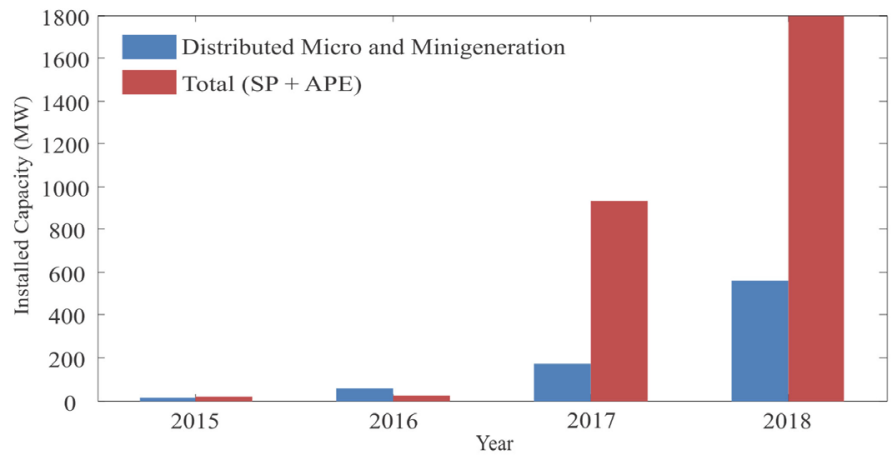

Figure 2. Installed capacity of the photovoltaic sector in Brazil [21].

The choice of installing a photovoltaic system in edifications is more viable when the utility tariff is more expensive and when the region's annual irradiation rate is high. Due to the continuous drop in prices of the photovoltaic sector in recent years, its adoption throughout Brazil has increased sharply to the point of exponential growth from 2016. Figure 3 shows the number of approvals of photovoltaic systems connected to the grid, accounting for a total of 57,555 installations until 2018.

The Southeast has the highest number of approvals, with 38596 installations corresponding to $46 \%$ of the total, followed by the South with 22,541 and $27 \%$, the Northeast with 11,430 and $13 \%$, the Midwest with 9355 and $11 \%$, and finally North with 2228 installations and 3\% of the total. One of the reasons for the difference in the number of installations among the regions of the country is due to the location of the headquarters of the companies that provide services in this sector. The region where companies generally start their activities and maintain their headquarters is the Southeast $(48.99 \%)$, followed by the South $(26.19 \%)$ [23]. Consequently, the two regions with the largest number of installations are leaders in the photovoltaic sector. The Northeast region has $12.29 \%$ of the headquarters, followed by the Midwest (10.71\%) and finally the North (1.83\%) [23]. These indicators show that the highest generation potentials are in the most populated regions of the country, places that may present lower irradiation, however, have a larger number of households and, consequently, a larger roof area [8]. 


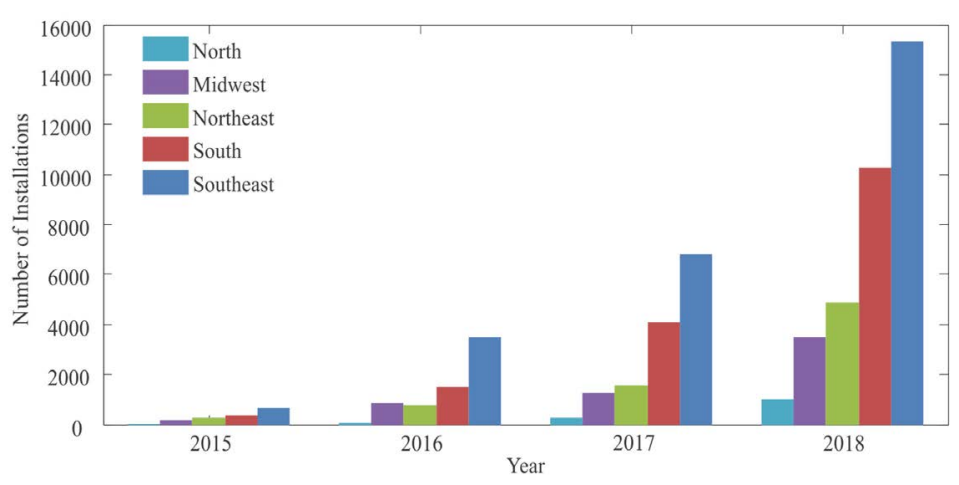

Figure 3. Number of photovoltaic installations by region of Brazil.

The Residential Tariff Class has 62,342 approved photovoltaic installations, followed by the Commercial Tariff Class with 14,443, Rural with 4489, Industrial with 2318 and finally the Public Sector (public lighting and public service) with 558 installations. The percentage distribution of installations by tariff class can be seen in Figure 4. A strong increase of projects in the rural area has been seen in recent years. In 2017, the installed capacity in rural projects was 9 MW; in 2018 increased to $47.2 \mathrm{MW}$; and by March 2019 it was already $60.3 \mathrm{MW}$. The state with higher photovoltaic generation capacity in the Rural area is Minas Gerais, followed by Rio Grande do Sul, Santa Catarina and São Paulo [22].

Photovoltaic systems are classified into three power ranges: 1) small size, with power from 0 to $12 \mathrm{~kW}$; 2) medium sized, with power from 13 to $200 \mathrm{~kW}$; 3 ) large size, with power higher than $201 \mathrm{~kW}$, [23]. Figure 5 shows the percentage distribution of photovoltaic installations by power range. Most installations are classified as small size, totaling 66,992 installations, with an average installed power of $4.5 \mathrm{~kW}$. In the medium size classification there are 14058 installations, with an average power of $34 \mathrm{~kW}$. Finally, in the large size classification there are 170 installations with $589 \mathrm{~kW}$ of average installed power.

The graphs presented in Figures 3-5 were created from an ANEEL database entitled Distributed Generation, which contains data from all homologations of consumer units of the photovoltaic type [24]. The bar chart contains information from 2015 to 2018, while the pie charts cover information from June/2007 to June/2019.

The costs related to the installation of photovoltaic systems have remained stable in recent years, that is, there have been no significant fluctuations in relation to component prices [25]. In Figure 6, it is possible to observe that the costs of photovoltaic modules and frequency inverter represent approximately $2 / 3$ of the total investment, information from June/2018 [25]. The national average cost of a photovoltaic installation (kit + integration) varies according to the segment and installed power, a Residential installation of $4 \mathrm{kWp}$ costs $1.08 \mathrm{U} \$ / \mathrm{Wp}$, a Commercial installation of $50 \mathrm{kWp}$ costs $0.83 \mathrm{U} \$ / \mathrm{Wp}$, while an Industrial installation of $1 \mathrm{MWp}$ costs $0.70 \mathrm{U} \$ / \mathrm{Wp}$ [23]. The photovoltaic kit represents an average of $67 \%$ of the total costs, while $33 \%$ is destined for integration (cables, connectors, disconnectors, protection devices and fixation structure). 


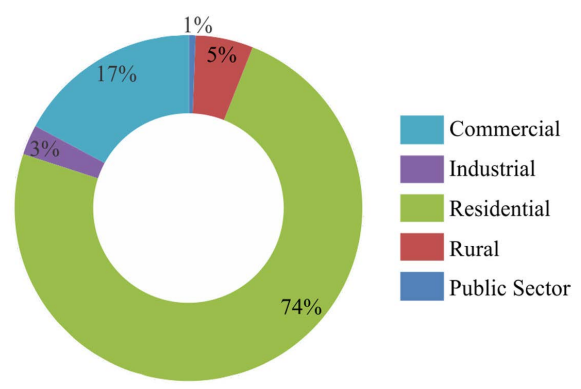

Figure 4. Percentage distribution of photovoltaic installations by tariff class.

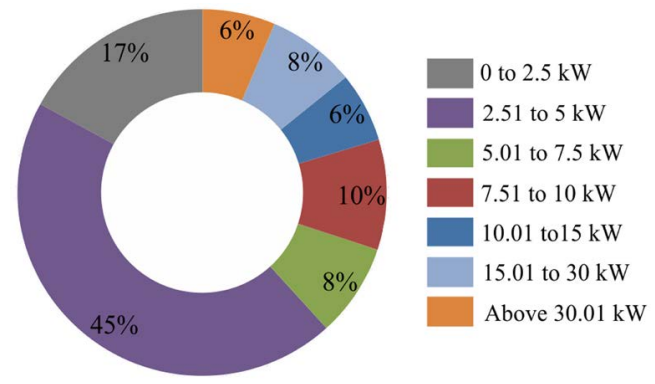

Figure 5. Percentage distribution of photovoltaic installations by power range.

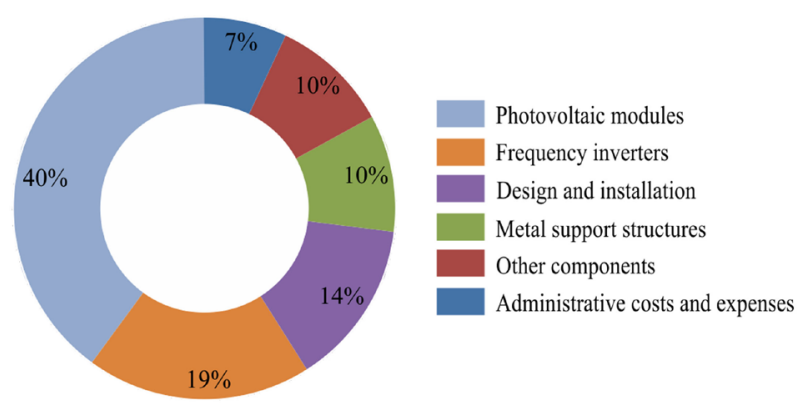

Figure 6. Costs distribution of a photovoltaic installation [25].

\section{Incentive Policies}

The incentives to join the distributed generation are justified by the countless benefits that are provided to the electrical system. In addition to diversifying the energy matrix, it reduces investments in expanding transmission and distribution systems, relieves grid load, reduces transport losses, and reduces environmental impacts. The cost of current generation (mainly from hydroelectric and thermoelectric) remains one of the main bottlenecks to justify the expansion of generation distributed in Brazil [26].

The Brazilian Federal Government changed Law No. 7689/1988 to Law No. $13169 / 2015$, seeking to encourage consumers to join the compensation system. Article 8 reduced to zero the PIS (Social Integration Program)/PASEP (Civil Servant Patrimony Formation Program)/COFINS(Contribution to Social Security Financing) contribution rates on the active electricity supplied by the distributor to the consumer unit, in the amount corresponding to the sum of the active electricity injected into the distribution grid by the same consumer unit, 
with active energy credits originating in the consumer unit itself in the same month, in previous months or in another consumer unit of the same holder, under the terms of the Electricity Compensation System for micro and minigeneration distributed, according to Normative Resolution No. 482/2012, [26]. The National Council of Fiscal Policy (CONFAZ), through the ICMS (Tax on Circulation of Goods and Services) Agreement 16, started in 2015 the authorizations for the states to grant exemption from the ICMS [19].

ANEEL and Ideal Institute have tools to promote micro and mini generation. ANEEL published the Thematic Books, as the "Mini and Microgeneration Distributed", which aims to demonstrate and exemplify the mechanisms for generating and compensating the energy produced through a photovoltaic system. The Ideal Institute grants the Solar Seal to companies or public institutions that use a minimum percentage of solar energy, published the Guide for the photovoltaic microgenerator, provides a photovoltaic simulator to assist in the dimensioning of the system, and maintains a Map of all companies in the photovoltaic sector [17].

In 2015, the Ministry of Mines and Energy (MME) launched the Distributed Electricity Generation Development Program (ProGD), created to encourage actions aimed at developing distributed renewable energy generation projects with a primary focus on photovoltaic solar energy [27].

The National Development Bank (BNDES) created the Progressive Nationalization Plan (PNP) to stimulate the development of a national production chain, aimed at the production of equipment and components for the photovoltaic area, thus avoiding the international monopoly of raw materials and guaranteeing the competitiveness of national industry [27].

\section{Credit Lines}

In 2017, the most used form of payment for the purchase of a photovoltaic system was cash. However, due to the emergence of new lines of financing and more attractive rates, in 2018 financing predominated. According to the IDEAL Institute study, financing represented $38 \%$ of payment options, $32 \%$ in cash, $18 \%$ in installments and the remaining $12 \%$ for other forms of payment [25].

Currently, several lines of financing for solar energy are offered in Brazil through public and private banks. Many of these loans make it possible to pay the installment with the savings obtained from the electricity bill, making the installation of photovoltaic systems more accessible to the population. Table 1 shows the most relevant credit lines for the solar sector, which offer greater benefits for the residential tariff class [29].

Banco do Brazil offers a solar energy consortium, while the other banks offer solar energy financing. Santander, Caixa Econômica Federal, BNDES Finame, Banco do Brasil, Bradesco and Banco Votorantinserve all Brazilianstates. All banks finance up to $100 \%$ of the investment, except Banco da Amazônia, which offers up to $70 \%$, considering the client's size, location and guarantees offered. 
Table 1. Financing lines for photovoltaic generation.

\begin{tabular}{|c|c|c|c|}
\hline Financial Institution & Interest Rate & $\begin{array}{c}\text { Maximum } \\
\text { Amount Financed }\end{array}$ & Installments \\
\hline Banco do Nordeste & $6.5 \%$ to $11 \%$ per annum & Up toU\$ $20,000.00$ & Up to 144 months \\
\hline Santander & $1.45 \%$ per month & - & Up to 36 months \\
\hline Sicredi & $1 \%$ to $3 \%$ per month & - & Up to 96 months \\
\hline Caixa Econômica & $1.40 \%$ to $1.85 \%$ per month & Up toU $\$ 35,000.00$ & Up to 240 months \\
\hline BNDES Finame & $\begin{array}{c}1.05 \% \\
\text { per annum }+ \text { institution rate }\end{array}$ & - & Up to 120 months \\
\hline Banco da Amazônia & $\begin{array}{c}1.14 \% \text { to } 3.27 \%+\text { IPCA } \\
\text { per annum }\end{array}$ & Up to $R \$ 30,000.00$ & Up to 96 months \\
\hline Banco do Brasil & $0.21 \%$ per annum & Up to $\mathrm{R} \$ 100,000.00$ & Up to 72 months \\
\hline Bradesco & $1.80 \%$ to $1.86 \%$ per month & - & Up to 60 months \\
\hline Banco Votorantin & $1.48 \%$ to $1.78 \%$ per month & Up to $\mathrm{R} \$ 100,000.00$ & Up to 60 months \\
\hline Unicred & $\mathrm{CDI}+0.49 \%$ per annum & - & Up to 120 months \\
\hline
\end{tabular}

\section{Future Perspectives}

Photovoltaic generation in Brazil has the potential to reach an installed capacity of $126 \mathrm{GWp}$ by the year 2040. This value will represent the equivalent of $32 \%$ of the Brazilian energy matrix, as shown in Figure 7. This sector will be driven mainly by small photovoltaic plants, which correspond to $95 \%$ of the total [28].

A highest part of investments in large size photovoltaic plants (Public Service Centers and Self-Producers) will be carried out before 2035. Small photovoltaic systems, consisting mainly of installations in homes and businesses, will have about US \$ 77 billion invested between 2020 and 2040, which will result in more than $100 \mathrm{GW}$ of installed capacity across the country [28].

The potential for solar generation in the country is over $28,500 \mathrm{GW}$ only with large size plants [27]. If the energy potential of solar generation is compared with the installed power of the Itaipu Hydroelectric Power Plant (14,000 MW), this represents only $0.05 \%$ of the installed capacity foreseen for Brazil. Distributed generation systems have a potential of $164 \mathrm{GW}$. These data do not consider regions with protected environmental areas, indigenous lands, quilombola communities and permanent preservation areas [27].

Currently, all energy produced through distributed generation photovoltaic systems can be discounted on consumers' electricity bills. However, ANEEL has proposed changes to normative resolution 482/2012, which have motivated discussions in the photovoltaic generation sector. ANEEL's intention is to offset the investments in infrastructure realized by energy distribution companies, through fees and charges that must be charged for the use of the distribution grid.

To promote the debate on the proposed improvement to resolution 482/2012, ANEEL put into public consultation the changes of the compensation system. The new resolution provides for a transition period for changes in the rules, in 


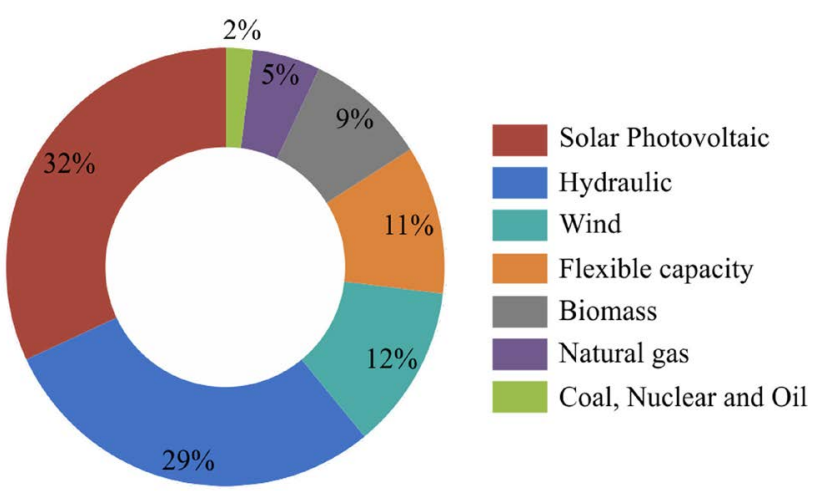

Figure 7. Projection of the Brazilian electric matrix in 2040 [28].

which consumers who already have the photovoltaic system will remain with the current rules in force until the year 2030. Consumers who realize the distributed generation installation after the publication of the updated standard, they started to pay the cost of using the energy distribution grid [30]. The period of contributions to the public consultation ended on December 30, 2019. So far, the process of updating the resolution is proceeding without due transparency, representing an unknown for society as to the direction that the distributed generation sector should take.

ANEEL argues that the maintenance of the current distributed generation model would generate extra costs of 11 billion dollars for the electricity system by 2035, reaching consumers who do not have a distributed generation system and would need to pay the fees and charges [28]. The argument has been supported by the Ministry of Economy. On the other hand, many companies and consumers who invested in this type of energy claim that the taxation creates legal uncertainty, since ANEEL promised predictability for 25 years and the investments were long-term.

\section{Conclusions}

The photovoltaic micro and mini generation grew after several incentives given by the government, together with the creation of Normative Resolution 482/2012, which exempted from taxes the energy generated by the photovoltaic system and injected into the distribution grid. Even with the rapid advancement of technologies for harnessing energy from the sun, photovoltaic generation has not yet reached $1 \%$ of the energy matrix in any Brazilian state. Thus, distributed generation still has negligible impacts on the grid and on the distributors' budget.

Photovoltaic solar energy started to stand out from the economic point of view as of 2017, due to the creation of new companies throughout the national territory. These companies faced the challenge of keeping prices competitive in the market, thus reducing their profit margins, due to the increase dollar between the years 2018 and 2020, and because most of the equipment destined for the photovoltaic market is imported.

The drop in the price of photovoltaic systems occurred mainly due to the in- 
crease in the manufacture of solar panels and technological advances in the semiconductor industry, responsible for more than $60 \%$ of the total cost of the installation, generating an increase in the yield and a decrease in the volume occupied by this equipment.

Consumers' concern with the environment, seeking clean and renewable energy sources, also contributed to the increased demand for photovoltaic systems. Associated with this, the civil construction sector started to use solar panels integrated to the architectural project, in addition to the generation of electric energy, seeking sustainable buildings with less ecological impact, such as the facades of large buildings and parking coverage.

At this moment, the legislation about compensation for energy generated through photovoltaic systems is being revised, indicating a reduction in benefits for consumers connected to the distribution grid. Even so, most studies foresee a significant increase in this sector for the next decades.

\section{Conflicts of Interest}

The authors declare no conflicts of interest regarding the publication of this paper.

\section{References}

[1] Teske, S., Sawyer, S., Schafer, O., Pregger, T., Simon, S., Naegler, T., Schmid, S., Ozdemir, E.D., Pagenkopf, J. and Kleiner, F. (2015) Energy Revolution-A Sustainable World Energy Outlook 2015. 364.

[2] Silva, R.C., Neto, I.M. and Seifert, S.S. (2016) Electricity Supply Security and the Future Role of Renewable Energy Sources in Brazil. Renewable and Sustainable Energy Reviews, 59, 328-341. https://doi.org/10.1016/j.rser.2016.01.001

[3] Prado, F.A., Athayde, S., Mossa, J., Bohlman, S., Leite, F. and Smith, A.O. (2016) How Much Is Enough? An Integrated Examination of Energy Security, Economic Growth and Climate Change Related to Hydropower Expansion in Brazil. Renewable and Sustainable Energy Reviews, 53, 1132-1136. https://doi.org/10.1016/j.rser.2015.09.050

[4] Tolmasquim, M.T. (2016) Energia renovável: Hidráulica, biomassa, eólica, solar, oceânica. Empresa de Pesquisa Energética (EPE), Rio de Janeiro, 452.

[5] Pinto, T.M., Amaral, K.J. and Janissek, P.R. (2016) Deployment of Photovoltaics in Brazil: Scenarios, Perspectives and Policies for Low-Income Housing. Solar Energy, 133, 73-84. https://doi.org/10.1016/j.solener.2016.03.048

[6] Ministério de Minas e Energia (2018) Premissas e Custos da Oferta de Energia Elétrica no horizonte 2050. Empresa de Pesquisa Energética, Rio de Janeiro, 53.

[7] Davidson, J. and Orner, F. (2008) The New Solar Electric Home-The Complete Guide to Photovoltaics for Your Home. Aatec Publications, Michigan, 472.

[8] Ministério de Minas e Energia (2018) Potencial dos Recursos Energéticos no horizonte 2050. Empresa de Pesquisa Energética, Rio de Janeiro, 133.

[9] Nemet, G.F. (2016) Beyond the Learning Curve: Factors Influencing Cost Reductions in Photovoltaics. Energy Policy, 34, 3218-3232. https://doi.org/10.1016/j.enpol.2005.06.020

[10] Pickerel, K. (2012) BOS Now Accounts for 68\% of Average PV System Pricing. 
http://solarbuildermag.com/news/bos-now-accounts-for-68-of-average-pv-system

[11] Montenegro, A.A. (2013) Avaliação do retorno do investimento em sistemas fotovoltaicos integrados a residências unifamiliares urbanas no Brasil. MSc Dissertation, Universidade Federal de Santa Catarina, Florianópolis.

[12] Pinho, J.T. and Galdino, M.A. (2014) Manual de Engenharia para Sistemas Fotovoltaicos. CEPEL-CRESESB, Rio de Janeiro, 530.

[13] ANEEL (2016) Micro e minigeração distribuída: Sistema de compensação de energia elétrica. Cadernos temáticos, Brasília, 31.

[14] ANEEL (2012) Resolução Normativa No. 482. http://www.aneel.gov.br/cedoc/ren2012482.pdf

[15] ANEEL (2012) Resolução Normativa No. 517. http://www.aneel.gov.br/cedoc/ren2012517.pdf

[16] ANEEL (2015) Resolução Normativa No. 687. http://www.aneel.gov.br/cedoc/ren2015687.pdf

[17] Consulo, M.T., Gimenes, A.L.V., Relva, S.G. and Udaeta, M.E.M. (2019) Basics on Energy Economics of Renewable Power Generation Projects: A Focus on Utility-Scale PV Plants Inclusion on National Grid. Proceedings IREC International Renewable Energy Congress, Sousse, 1-6. https://doi.org/10.1109/IREC.2019.8754593

[18] ANEEL (2015) Resolução Normativa No. 674. http://www2.aneel.gov.br/cedoc/ren2015674.pdf

[19] Assad, V.C.D. and Batista, O.E. (2011) Scenario and Perspective of Distributed Generation in Brazil. Proceedings SBSE Simpósio Brasileiro de Sistemas Elétricos, Niterói, 1-5.

[20] INMETRO (2011) Requisitos de Avaliação da Conformidade para Sistemas e Equipamentos para Energia Fotovoltaica. http://www.inmetro.gov.br/legislacao/rtac/pdf/RTAC001652.pdf

[21] EPE (2019) Brazilian Energy Balance 2019 Year 2018. Rio de Janeiro, 300.

[22] IRENA (2019) Renewable Energy Statistics 2019. Abu Dhabi, 398.

[23] Greener (2019) Pesquisa e Consultoria. Estudo Estratégico: Mercado Fotovoltaico de Geração Distribuída $2^{\circ}$ sem 2018. São Paulo, 145.

[24] ANEEL (2019) Geração Distribuída UFV. http://www2.aneel.gov.br/scg/gd/gd fonte detalhe.asp?tipo=12\&pagina $=70$

[25] Instituto IDEAL (2019) O mercado brasileiro de geração distribuída fotovoltaica. Santa Catarina, 66.

[26] Schutze, A. and Assunção, J.J. (2017) Developing Brazil's Market for Distributed Solar Generation. Núcleo de Avaliação de Políticas Climáticas PUC-Rio, Rio de Janeiro, 6.

[27] Correa, R.B., Asano, P.T.L., Benedito, R.S., Chung, H. and Jonathan, S. (2018) Financial Impact of Solar Distributed Generation's Growth on Distribution Companies' Revenue. Proceedings SBSE Simposio Brasileiro de Sistemas Eletricos, Niteroi, 1-5. https://doi.org/10.1109/SBSE.2018.8395777

[28] Bloomberg New Energy Finance (2019) New Energy Outlook 2018. Nova York, 36.

[29] Colaferro, J.R.Q. (2020) Financiamento da Energia Solar. http://blog.bluesol.com.br/financiamento-de-energia-solar

[30] Silva, R.M. (2019) O Novo Arranjo Regulatório Proposto pela ANEEL para a Geração Distribuída na Consulta Pública N. 25 de 2019. CONLEG, Brasília, 21. 